\title{
Özel Durumlarda Tedavi
}

Öz

Akne tedavisi bir bilim olduğu kadar aynı zamanda sanattır. Tedavinin kişiselleştirilmesi ve uygun hastaya uygun tedavi verilmesi kapsamında özellikle doğurganlık çağındaki kadınlar ve sistemik hastalık varlığı önem arzetmektedir. Akne tedavisi gebe kalmaya çalışanlar, gebe ve emzirenler ile sistemik hastalıkları olanlar için güvenli olacak şekilde ayarlanmalıdır. Bu bölümde gebelik, emzirme ve nöropsikiyatrik, kardiyovasküler, solunum yolu, karaciğer, böbrek ve gastrointestinal sistem hastalıkları gibi bazı sistemik hastalıklar varlığında akne tedavisi irdelenecektir.

Anahtar Kelimeler: Akne tedavisi, gebelik, emzirme

\begin{abstract}
Treatment of acne is an art as much as a science. Women at reproductive age and presence of any systemic disease are two important considerations in personalizing the treatment and providing appropriate treatment to appropriate patient. Acne treatment should be organised in a way to be safe for those who try to become pregnant, who are pregnant and breastfeeding, and who have systemic diseases. This section will cover acne treatment in the presence of pregnancy, breastfeeding and some systemic diseases including neuropsychiatric, cardiovascular, respiratory, hepatic, renal, and gastrointestinal.
\end{abstract}

Keywords: Acne treatment, pregnancy, breastfeeding

\section{Giriş}

Gebeler ve emzirenlerde akne tedavisinde kullanılan ilaçların güvenliği ile ilgili bilgiler sınırlıdır, klinik çalışmalara bu grup hastalar dahil edilmediği için elde var olan bilgiler olgu sunumları ve hayvan çalışmalarından elde edilmiştir. Var olan bilgilerin sınırlı olması, yeterli sınıflandırmaların olmaması, teratojenite gibi ciddi yan etki ihtimalinin var olması ve pek çok klinisyenin akneyi kozmetik bir problem olarak kabul etmesi sonucunda gebe ve emziren kadınlarda sıklıkla daha az etkili tedaviler verilmekte ya da hiç tedavi verilmemektedir. Doğurganlık çağındaki kadınlar üreme planları açısından sorgulanmalı ve tedavi gebe kalmaya çalışanlar, gebe ve emzirenler için güvenli olacak şekilde ayarlanmalıdır. Gebe ve emziren kadınlarda topikal ajanların sistemik emilimlerinin çok düşük olması nedeniyle sistemik olarak kullanılan akne tedavi ajanlarından daha güvenilir oldukları düşünülmektedir ${ }^{1}$.

Bu bölümde gebelik, emzirme ve bazı sistemik hastalıklar varlığında akne tedavisi irdelenecektir. Aynı zamanda nöropsikiyatrik, kardiyovasküler, solunum yolu, karaciğer, böbrek ve gastrointestinal sistem hastalıkları gibi sistemik hastalıklar varlığında da akne tedavisi bazı önemli ayrıntılar içermektedir.

Yazıșma Adresi/Address for Correspondence: Doç. Dr. Berna Aksoy

Bahçeşehir Üniversitesi Tıp Fakültesi, Dermatoloji Anabilim Dalı, İstanbul, Türkiye

E-posta: bernaaaksoy@gmail.com ORCID: orcid.org/0000-0003-2346-1865

C Telif Hakkı 2020 Deri ve Zührevi Hastalılar Derneği

Türkderm - Türk Deri Hastalıkları ve Frengi Arșivi, Galenos Yayınevi tarafından basılmıștır. 


\section{Gebelik}

- Gebeliğin fizyolojik belirtilerinden birisi de androjen düzeylerinde yükselme sonucu seborenin artması ve genellikle var olan aknenin kötüleşmesidir ${ }^{1}$.

- Akne tedavisinde kullanılan ilaçların Gıda ve ilaç İdaresi (FDA) sınıflamasına göre risk kategorileri Tablo 1'de gösterilmiş̧ir. Bu kategoriler yıllar boyunca uygulamada kaldı, ancak basit olmaları ve gebelik, emzirme ve doğurganlık çağındaki kadın ve erkeklerde ilaçların kullanımı açısından ayrıntılı bilgi içermemeleri nedeniyle zaman içinde değiştirilme gereği duyularak 30.06.2015 yılında Gebelik ve Emzirme Etiketleme Nihai Kuralı uygulamaya girdi. Bu tarihten önce başvuru yapmış ilaçların da zaman içinde bu yeni kurallara göre sınıflandırılması planlandı (https://www.drugs.com/pregnancy-categories.html, erişim tarihi 17.05.2019).

- Gebelikte risk tanımlaması için çalışmalardan elde edilen bilgiler kullanılarak; risk yok, düşük, orta, yüksek ve yetersiz bilgi şeklinde sınıflandırımaktadır. Emzirme döneminde kullanım ile ilgili olarak insan sütünde ilaç mevcudiyeti, emzirilen çocukta ilacın etkileri, ilacın süt üretimine etkileri, klinik değerlendirme ve risk özeti bilgileri bulunmaktadır. Doğurganlık çağındaki kadın ve erkek bölümünde gebelik testi, kontrasepsiyon ve infertilite ile ilgili bilgiler bulunmaktadır (https://s3.amazonaws.com/public-inspection.federalregister. gov/2014-28241.pdf)

\section{Gebelikte topikal akne tedaviler}

-Topikal retinoidler özellikle de tazaroten sistemik emilimleri düşük olsa da teratojen oldukları için gebelikte kullanılmamalıdırlar ${ }^{2,3}$.

- Benzoil peroksit (BPO) gebelikte sınılı alanda kullanılabilir ${ }^{2,3}$. BPO deride emildikten sonra benzoik asite metabolize olur, topikal uygulama sonras maruz kalınan benzoik asit miktarı diyetle alınan benzoik asitten daha azdır ${ }^{3}$. - Tek başına kullanılan topikal antibiyotiklerden eritromisin, klindamisin ve metronidazolün elde olan az bilgiye istinaden bilinen fetal etkisi yoktur ve gebelikte kullanımı güvenli kabul edilmektedir.

- Topikal salisilik asit eğer kısa süreli ve sınırlı alana uygulanırsa fetal risk oluşturmamaktadır2,3

Tablo 1. Akne tedavisinde kullanılan ilaçların Gıda ve İlaç İdaresi risk sınıflaması

\begin{tabular}{|l|l|l|}
\hline $\begin{array}{l}\text { FDA risk } \\
\text { kategorisi }\end{array}$ & Form & Terapötik ajan \\
\hline B & Topikal & Eritromisin, klindamisin, azelaik asit \\
\cline { 2 - 3 } & Sistemik & $\begin{array}{l}\text { Eritromisin, azitromisin, amoksisilin, } \\
\text { sefaleksin }\end{array}$ \\
\hline C & Topikal & $\begin{array}{l}\text { BPO, kombine BPO + eritromisin / } \\
\text { klindamisin, tretinoin, adapalen, klindamisin } \\
+ \text { tretinoin, adapalen + BPO, dapson, salisilik } \\
\text { asit }\end{array}$ \\
\cline { 2 - 3 } & Sistemik & $\begin{array}{l}\text { Trimetoprim +/-sülfametoksazol, } \\
\text { spironolakton, kortikosteroidler }\end{array}$ \\
\hline D & Topikal & - \\
\cline { 2 - 3 } & Sistemik & Tetrasiklin, doksisiklin, minosiklin, flutamid \\
\hline X & Topikal & Tazaroten \\
\cline { 2 - 3 } & Sistemik & İzotretinoin, KOK \\
\hline FDA: Gida ve ilaç idaresi, BPO: Benzoil peroksit, KOK: Kombine oral kontraseptifler \\
\hline
\end{tabular}

- Azelaik asit hafif komedolitik, antibakteriyel ve anti-enflamatuvar etkiye sahip olup FDA tarafından güvenli kabul edilmektedir. Doğurganlık çağındaki kadınlarda kullanılabilecek önemli bir alternatiftir ${ }^{2,4}$.

\section{Gebelikte sistemik akne tedavileri}

- Antibiyotiklerden tetrasiklin, doksisiklin ve minosiklin kemik ve diş yan etkileri nedeniyle gebelikte önerilmez ${ }^{2,3}$. Tetrasiklinlere ilk trimesterde istemsiz maruz kalınabilmektedir ve bunun sonucunda herhangi bir konjenital malformasyon bildirilmemiştir ${ }^{1,3}$, ancak yine de kullanılmaması önerilmektedir.

- Trimetoprim (TMP) folik asit metabolizmasını etkileyerek ilk trimesterde nöral tüp defektleri, yarık damak ve dudak ile kardiyovasküler ve üriner sistem malformasyonlarına neden olabileceği; sülfonamidler de peripartum dönemde kullanıldığında yenidoğanda kernikterusa neden olabilecekleri için kontrendikedir ${ }^{3}$.

- Gebelikte oral eritromisin ve azitromisin sistemik antibiyotik olarak tercih edilebilse de monoterapi olarak önerilmez ${ }^{1-3}$. Eritromisin her ne kadar gebelikte ikinci ve üçüncü trimesterde güvenli ve birinci seçenek kabul edilse de ilk trimesterde kullanımı sonucu bildirilmiş fetal kardiyak malformasyon olguları bulunmaktadır ve uzun süreli kullanımda gebelerin \%10-15'inde hepatotoksisite bildirilmiştir ${ }^{1}$. Gebelikte eritromisin estolat ikinci trimesterde annede \%10 oranında hepatotoksisiteye neden olacağı için kullanılmaz. Gebelikte eritromisin baz ya da eritromisin etilsüksinat kullanılmalıdır ${ }^{3}$.

- Azitromisin hakkında bilgilerimiz sınırlıdır ve eritromisinden sonra ikinci tercih olarak önerilmektedir ${ }^{3}$.

- Amoksisilin ve sefaleksin akne tedavisi uygulanan gebe hastalarda adjuvan tedavi olarak tercih edilecek antibiyotiklerdendir ${ }^{1,2}$.

- Kombine oral kontraseptifler (KOK) gebelikte önerilmez. KOK kullanımı öncesi gebelik testi yapılmalıdır².

- Spironolakton gebelikte erkek fetüste feminizasyona neden olabileceği için kontrendikedir².

- Sistemik izotretinoin gebelik kategorisi X olduğu için gebelikte ya da gebelik planlayan kadın hastalarda kontrendikedir ${ }^{1,2}$

\section{Emzirme}

- Emzirme döneminde ilaç kullanımı açısından en sık kullanılan risk sınıflama sistemleri Amerikan Pediatri Akademisi ve yakın zamanda yayınlanan Amerikan Ulusal Tıp Kütüphanesi tarafından oluşturulan İlaç ve Emzirme veri tabanıdır'. Akne tedavisinde kullanılan ilaçların emzirme döneminde sınıflandırılması Tablo 2'de gösterilmiştir.

\section{Emzirme döneminde topikal akne tedavileri}

- Topikal retinoidlerden adapalen, tretinoin ve tazarotenin anne sütüne geçip geçmediği bilinmemektedir². Adapalen vücutta geniş yüzeylere uygulanmadığı takdirde sistemik emilimi düşük miktarda olacağı için emzirme döneminde kullanılabilir. Tretinoin doğal A vitamini izomeri olduğu için normalde anne sütünde bulunabilmektedir, topikal uygulama sonrası sistemik emilim düşük miktarda olacağı için emzirme döneminde kullanımı güvenlidir ${ }^{5}$. Tazaroten topikal olarak vücutta geniş yüzeylere uygulanmadığı takdirde sistemik emilimi çok düşük miktarda olacağı için emzirme döneminde kullanımı orta düzeyde güvenlidir ${ }^{3,5}$.

- Topikal BPO'nun emilerek insan sütüne geçip geçmediği bilinmemektedir². Emzirme döneminde kullanılmaya uygundur ${ }^{1,5}$.

- Salisilik asit emzirme döneminde kullanılmamalı ya da kullanılacak ise emzirme kesilmelidir. Eğer emzirme döneminde kullanılırsa göğüs bölgesine uygulamadan kaçınılmalıdır. 
- Eritromisin ve klindamisinin topikal uygulama sonrası anne sütüne geçip geçmediği bilinmemektedir². Topikal eritromisin, klindamisin ve metronidazol emzirme döneminde güvenlidir ve kullanılabilir ${ }^{1,5}$.

- Topikal olarak uygulanan azelaik asit anne sütüne minimal düzeyde geçmektedir ve emziren annelerde kullanımı güvenlidir ${ }^{2,4}$.

- Dapson anne sütüne geçmektedir. Emzirilen infantlarda oral dapsonun yan etkilere neden olduğu bilindiği için, topikal dapson akne tedavisinde emzirme sırasında kullanılmamalı ya da mutlaka kullanılacak ise emzirme durdurulmalıdır².

\section{Emzirme döneminde sistemik akne tedavileri}

- Tetrasiklin, doksisiklin ve minosiklin anne sütüne geçmektedir, ancak anne sütünde kalsiyuma güçlü bir şekilde bağlandığı için infant

Tablo 2. Akne tedavisinde kullanılan ilaçların emzirme döneminde kullanımları ile ilgili sınıflandırılması

\begin{tabular}{|c|c|c|c|}
\hline Form & Terapötik ajan & $\begin{array}{l}\text { Amerikan } \\
\text { Pediatri } \\
\text { Akademisi } \\
\text { sınıflaması }\end{array}$ & $\begin{array}{l}\text { İlaç ve Emzirme } \\
\text { veri tabanı } \\
\text { sınıflaması }\end{array}$ \\
\hline \multirow[t]{6}{*}{ Topikal } & $\mathrm{BPO}$ & Sınıflandırılmamış & Düşük risk \\
\hline & $\begin{array}{l}\text { Topikal } \\
\text { antibiyotikler } \\
\text { (eritromisin, } \\
\text { klindamisin) }\end{array}$ & Uygun & Kabul edilebilir \\
\hline & $\begin{array}{l}\text { Topikal } \\
\text { retinoidler } \\
\text { (tretinoin, } \\
\text { adapalen, } \\
\text { tazaroten) }\end{array}$ & Sınıflandırılmamış & Düşük risk \\
\hline & Azelaik asit & Sınıflandırılmamış & Düşük risk \\
\hline & Dapson & Uygun & $\begin{array}{l}\text { Yenidoğan, } \\
\text { prematür ve } \\
\text { G6PD eksikliğinde } \\
\text { kaçınılmalı }\end{array}$ \\
\hline & Salisilik asit & Sınıflandırılmamış & Sınıflandırılmamış \\
\hline \multirow[t]{8}{*}{ Sistemik } & $\begin{array}{l}\text { Tetrasiklinler } \\
\text { (tetrasiklin, } \\
\text { doksisiklin, } \\
\text { minosiklin) }\end{array}$ & Uygun & $\begin{array}{l}\text { Kısa süreli } \\
\text { kullanım kabul } \\
\text { edilebilir }\end{array}$ \\
\hline & $\begin{array}{l}\text { Makrolidler } \\
\text { (eritromisin, } \\
\text { azitromisin) }\end{array}$ & Uygun & Kabul edilebilir \\
\hline & $\begin{array}{l}\text { Trimetoprim +/- } \\
\text { sülfametoksazol }\end{array}$ & Uygun & $\begin{array}{l}\text { Sarılığı olan, } \\
\text { prematür ve } \\
\text { hasta infantlarda } \\
\text { kaçınılmalı }\end{array}$ \\
\hline & İzotretinoin & Sınıflandırılmamış & $\begin{array}{l}\text { Öneri yok } \\
\text { (kullanılmamalı) }\end{array}$ \\
\hline & KOK & Uygun & $\begin{array}{l}\text { Postpartum ilk } 4 \\
\text { hafta kaçınılmalı }\end{array}$ \\
\hline & Spironolakton & Uygun & $\begin{array}{l}\text { Kabul edilebilir } \\
\text { görünmekte }\end{array}$ \\
\hline & Flutamid & Sınıflandırılmamış & Öneri yok \\
\hline & Kortikosteroidler & Uygun & Kabul edilebilir \\
\hline
\end{tabular}

BPO: Benzoil peroksit, G6PD: Glukoz-6-fosfat dehidrogenaz eksikliği, KOK: Kombine oral kontraseptifler maruziyeti düşük oranda gerçekleşmekte ve emzirme döneminde kısa süreli (<3 hafta) kullanımı güvenli kabul edilmektedir,3,5.

- TMP-sülfametoksazol (SMX) anne sütüne geçer². Bebek prematür, glukoz-6-fosfat dehidrogenaz eksikliği ya da ciddi sarılığa sahip değilse emzirme döneminde TMP-SMX kullanımı güvenli kabul edilmektedir.

- Sistemik eritromisin ve azitromisin anne sütüne geçer ancak emziren annelerde güvenli kabul edilmektedir ${ }^{1,5}$. Eritromisin erken postpartum dönemde infantil hipertrofik pilor stenozuna neden olabileceği için kullanılmamalıdır ${ }^{3,5}$.

- Amoksisilin ve sefaleksin infant için minimal risk taşıdığı için emzirme sırasında akne tedavisinde güvenli adjuvan tedavi olarak kullanılabilirler ${ }^{2,5}$.

- KOK'ler emzirme döneminin ilk 6 haftasında önerilmezler. Doğum sonrası 6 hafta ile 6 ay arasında dikkatli ve özel takiple kullanımaları önerilir. Emzirme döneminde etinil estradiol ve norgestimate içeren KOK'ler adjuvan tedavi olarak kullanılabilir. Ancak noretindron asetat ve drospirenon içeren KOK'lerin infant üzerine etkileri tam olarak bilinmediği için Dünya Sağlık Örgütü tarafından emzirme döneminde kullanılmamaları önerilmektedir. Amerikan Pediatri Akademisi ise drospirenon içeren KOK'lerin emzirme sırasında kullanılabileceğini belirtmektedir. Spironolakton infant için minimal risk taşıdığı için emzirme sırasında kullanılabilir².

- Sistemik izotretinoinin emzirme sırasında kullanımı ile ilgili yeterli veri bulunmamaktadır². Ancak infantta ciddi toksisiteye neden olabileceği ve anne sütüne geçebileceği için emzirme döneminde kullanılmamalıdır ${ }^{5}$.

\section{Nöropsikiyatrik hastalıklar}

- Topikal (tek başına ya da kombinasyon halinde) veya oral yolla kullanılan klindamisin nöromüsküler bloke edici özellikler taşıdığı için diğer nöromüsküler bloke edici ajanlar ile birlikte kullanılmamalıdır.

- Topikal dapson yan etki olarak baş ağrısı, depresyon, intihar girişimi, psikoz ve tonik klonik kasılmalara neden olabileceği için nöropsikiyatrik hastalıkları olanlarda dikkatli kullanılmalıdır. Topikal dapson ayrıca antikonvülzanlar ile etkileşime gireceği için birlikte kullanımamalıdır².

- Minosiklin konvülziyonlara neden olabildiği için epilepsi hastalarında kullanılmamalıdır.

- Doksisiklin de antikonvülzanlarla etkileşime gireceği için yine epilepsi hastalarında kullanılmamalıdır.

- Sistemik eritromisin, azitromisin ve amoksisilin konvülziyonlara neden olabildiği için epilepsi hastalarında kullanıımamalıdırlar².

- Fokal nörolojik belirtilerle seyreden baş ağrısı (migren) olan hastalarda KOK'ler kontrendikedir. KOK'ler depresyon ve duygu durum değişikliklerine neden olabileceği için psikiyatrik hastalık öyküsü olanlarda dikkatli kullanılmalıdır. KOK'ler ayrıca antikonvülzan ilaçlar ile etkileşime girdiği için birlikte kullanılmamalıdırlar².

- Sistemik izotretinoin psödotümör serebri ve nöbetlere neden olabilir. Psödotümör serebri gelişme riski nedeniyle sistemik izotretinoin ile eşzamanlı olarak sistemik tetrasiklin, doksisiklin veya minosiklin kullanılmamalıdı².

- Sistemik izotretinoin kullanımı ile ilgili duygu durum değişiklikleri, depresyon, intihar ve psikoz geliştiğini belirten yayınlar olduğu için psikiyatrik hastalığı olanlarda dikkatli kullanılmalı² ve bipolar bozukluğu olanlarda atakları tetikleyebileceği için kullanılmamalıdırlar. Hastalar sistemik izotretinoin tedavisi öncesi ve sırasında psikiyatrik açıdan değerlendirilerek dikkatli takip edilmelidir². 
- Ciddi depresyon ve psikoz varlığında intralezyoner steroid enjeksiyonlar kontrendikedir ${ }^{2}$ (Tablo 3).

\section{Kardiyovasküler sistem hastalıkları}

- Sistemik eritromisin ve azitromisin çarpıntı, aritmi, QT aralığı uzaması ve Torsade de Pointes sendromuna neden olabilecekleri için kalp ritm bozukluğu olan ve antiaritmik kullanan hastalarda kullanılmamalıdırlar². - Tıbbi öyküsünde serebrovasküler hastalık, kalp damar hastalığı, komplikasyonlar ile birlikte kalp kapak hastalığı, derin ven trombozu, tromboembolik hastalıklar öyküsü olan, kan basıncı 160/100 mmHg'den daha yüksek veya ciddi hipertansiyonu olan hastalarda KOK'ler kontrendikedir. KOK kullanımı öncesi kan basıncı ölçümü yapılmalıdır

- Kalp yetmezliği ve ciddi hipertansiyonu olan hastalarda intralezyoner steroid enjeksiyonları kontrendikedir² (Tablo 3).

\section{Solunum yolu hastalıkları}

- Topikal olarak uygulanan klindamisin ve kombine klindamisin ile tretinoin preparatları yan etki olarak nazofarenjit, sinüzit, faringolarenjiyal ağrı ve öksürüğe neden olabileceği, klindamisine bağlı pnömonit bildirilmiş olduğu için solunum yolu hastalıkları olanlarda dikkatli kullanılmalıdırlar ${ }^{2,6}$.

- Dapsonun eozinofilik pnömonit yapabildiği bildirilmiş ve yan etki olarak grip, farenjit, nazofarenjit, üst solunum yolu enfeksiyonları, sinüzit ve öksürüğe neden olabileceği için topikal dapson preparatları solunum yolu hastalıkları olanlarda dikkatli kullanılmalıdırlar ${ }^{2,7}$.

- Minosiklin bronkospazm, pnömonit ve astım alevlenmesine neden olabileceği için kronik solunum yolu hastalığı (astım, kronik obstrüktif akciğer hastalığı) olanlarda kullanıımamalıdır².

- Aktif tüberkülozu olan hastalarda yüksek dozda intralezyoner steroid enjeksiyonu uygulanmamalıdır² (Tablo 3).

Tablo 3. Sistemik hastalık varlığında dikkatli kullanılması gereken akne tedavi ajanları

\begin{tabular}{|l|l|}
\hline $\begin{array}{l}\text { Sistemik } \\
\text { hastalık }\end{array}$ & Dikkatli kullanılması gereken tedavi ajanları \\
\hline Nöropsikiyatrik & $\begin{array}{l}\text { Topikal klindamisin, dapson } \\
\text { Sistemik klindamisin, doksisiklin, minosiklin, } \\
\text { eritromisin, azitromisin, amoksisilin, izotretinoin, } \\
\text { KOK } \\
\text { İntralezyoner steroidler }\end{array}$ \\
\hline Kardiyovasküler & $\begin{array}{l}\text { Sistemik eritromisin, azitromisin, KOK } \\
\text { Intralezyoner steroidler }\end{array}$ \\
\hline Solunum yolu & $\begin{array}{l}\text { Topikal klindamisin - tretinoin kombinasyonu, } \\
\text { dapson } \\
\text { Sistemik minosiklin } \\
\text { Intralezyoner steroidler }\end{array}$ \\
\hline Karaciğer & $\begin{array}{l}\text { Topikal salisilik asit } \\
\text { Sistemik minosiklin, doksisiklin, tetrasiklin, TMP- } \\
\text { SMX, eritromisin, azitromisin, amoksisilin, KOK, } \\
\text { flutamid }\end{array}$ \\
\hline Böbrek & $\begin{array}{l}\text { Sistemik minosiklin, TMP-SMX, amoksisilin, } \\
\text { sefaleksin, spironolakton }\end{array}$ \\
\hline Gastrointestinal & $\begin{array}{l}\text { Topikal eritromisin, klindamisin, dapson } \\
\text { Sistemik tetrasiklin, doksisiklin, minosiklin }\end{array}$ \\
\hline KOK: Kombine oral kontraseptifler, TMP: Trimetoprim, SMX: Sülfametoksazol \\
\hline
\end{tabular}

\section{Karaciğer ve böbrek hastalıkları}

- Varisella ya da influenza benzeri hastalığı olan çocuklarda topikal salisilik asit preparatlarının kullanımı artmış Reye sendromu gelişimi riski nedeniyle önerilmez ${ }^{2}$.

- Tetrasiklin, doksisiklin ve özellikle de minosiklin hepatotoksisite, hepatit ve karaciğer yetmezliğine neden olabilir. Aynı zamanda doz bağıml olarak kan üre azotunun yükselmesi, nefrit ve böbrek yetmezliğine neden olabilirler².

- Doksisiklin karaciğerde metabolize edildiği için renal hastalığı olanlarda güvenle kullanılabilir ${ }^{1}$.

- TMP-SMX ileri düzeyde karaciğer ve böbrek bozukluğu olanlarda kontrendikedir. TMP-SMX kolestatik sarılık, hepatit, karaciğer nekrozu, nefrit ve böbrek yetmezliğine neden olabileceği için dikkatli kullanımalıdır. Aynı zamanda serum transaminaz, bilirubin, kan üre azotu ve kreatinin düzeyi yükselmesine neden olarak kreatinin testi ile etkileşebilir².

- Sistemik eritromisin ve azitromisin karaciğerde kolestatik sarılık ve hepatik fonksiyon bozukluğuna neden olabilir, bu nedenle daha önceki kullanımında bu yan etkiler gelişen hastalarda kontrendikedir ${ }^{2}$.

- Sistemik amoksisilin kullanımı sırasında transaminaz düzeylerinde yükselme, kolestatik sarılık ve hepatit görülebileceği için karaciğer hastalığı olanlarda dikkatli kullanımalıdı²

- Renal fonksiyon bozukluğu olan hastalarda amoksisilin ya da sefaleksin kullanımı sırasında doz ayarlaması yapılmalıdır².

- Anormal karaciğer fonksiyon bozukluğu ile beraber olan hepatoselüler hastalık, hepatik adenom ve karsinom, gebelikte kolestatik sarılık öyküsü ya da daha önceki KOK kullanımı ile sarılık öyküsü olan hastalarda KOK kullanımı kontrendikedir².

- Böbrek yetmezliği olan hastalarda spironolakton kullanımı kontrendikedir².

- Karaciğer yetmezliği olan hastalarda flutamid kontrendikedir ve tedavi öncesi mutlaka karaciğer fonksiyon testleri değerlendirilmelidir² (Tablo 3).

\section{Gastrointestinal hastalıklar}

- Topikal (tek başına ya da kombinasyon halinde) veya oral yolla kullanılan eritromisin ve klindamisin psödomembranöz kolite neden olabileceği için dikkatli kullanılmalıdır².

- Topikal (tek başına ya da kombinasyon halinde) veya oral yolla kullanılan klindamisin rejyonel enterit, ülseratif kolit veya antibiyotik ilişkili kolit öyküsü varlığında kontrendikedir².

- Topikal dapson yan etki olarak karın ağıısı, şiddetli kusma ve pankreatit gelişimine neden olabileceği için öyküde bu belirtileri ve pankreatit riski olan hastalarda dikkatli kullanımalıdır².

- Tetrasiklin, doksisiklin ve minosiklin kullanımında görülebilen çeşitli gastrointestinal sistem yan etkilerinin yanısıra özofajit ve özofageal ülserasyon riski taşıması nedeniyle bu ilaçların doğru kullanımı (bol su ile alınması ve kullanım sonrası en az yarım saat dik kalınması) konusunda hastalar eğitilmelidir (Tablo 3).

\section{Kaynaklar}

1. Tan AU, Schlosser BJ, Paller AS: A review of diagnosis and treatment of acne in adult female patients. Int J Womens Dermatol 2017;4:56-71. 
2. Zaenglein AL, Pathy AL, Schlosser BJ, et al: Guidelines of care for the management of acne vulgaris. J Am Acad Dermatol 2016;74:945-73.

3. Murase JE, Heller MM, Butler DC: Safety of dermatologic medications in pregnancy and lactation: Part I. Pregnancy. J Am Acad Dermatol 2014;70:401.

4. Bagatin E, Freitas THP, Machado MCR, et al: Adult female acne: a guide to clinical practice. An Bras Dermatol 2019;94:62-75.
5. Butler DC, Heller MM, Murase JE: Safety of dermatologic medications in pregnancy and lactation: Part II. Lactation. J Am Acad Dermatol 2014;70:417.

6. Kohno S, Yamaguchi K, Yasuoka A, et al: Clinical evaluation of 12 cases of antimicrobial drug-induced pneumonitis. Jpn J Med 1990;29:248-54.

7. Kaur J, Khandpur S, Seith A, Khanna N: Dapsone-induced eosinophilic pneumonitis in a leprosy patient. Indian J Lepr 2005;77:267-71. 